\title{
SERUM HOMOCYSTEINE LEVELS IN PATIENTS WITH ACUTE MYOCARDIAL INFARCTION
}

\author{
ALAM N ${ }^{1}, \mathrm{CHOWDHURY} \mathrm{AW}^{1}$, HOSSAIN MZ ${ }^{2}, \mathrm{KHONDOKER} \mathrm{MAH}^{1}, \mathrm{MALLIK} \mathrm{MU}^{2}$, AMIN MR $^{3}$, \\ HASAN GMS ${ }^{4}$
}

\begin{abstract}
In the pathogenesis of acute coronary syndrome besides the traditional risk factors certain emerging risk factors are getting attention now a days. Serum homocysteine is a newly recognized cardiovascular risk factor that is associated with increased thrombosis and atherosclerotic tendency. The objective of the present study was to assess the serum homocysteine level in acute myocardial infarction patients. This was a cross sectional study conducted among the patients with acute myocardial infarction admitted in the Department of Cardiology, Dhaka Medical College Hospital during the period of October 2009 to September 2010. A total of 194 consecutive patients with acute myocardial infarction (MI) were included in the study. The mean $( \pm S D)$ serum homocysteine level was $20.2 \pm 14.3 \mathrm{mmol} / \mathrm{L}$ with range from 7.4 to 129.1 $\mathrm{mmol} / \mathrm{L}$. The main observation of the present study was that significant number (61.9\%) of patients of acute myocardial infarction had elevated serum homocysteine level. Another finding was that patients with moderate hyperhomocysteinemia (e"15 mmol/L) was found to be 7.09 times more likely to have increased serum troponin-I (a surrogate marker of extent of myocardial injury). This study suggests that other than the traditional risk factors with the development of atherosclerotic coronary artery disease hyperhomocysteinemia should be on special focus as well.
\end{abstract}

J Dhaka Med Coll. 2012; 21(1) : 23-27.

\section{Introduction}

Acute myocardial infarction (AMI) remains a leading cause of morbidity and mortality worldwide. Primary risk factors have been identified with the development of atherosclerotic coronary artery disease and MI. These are hyperlipidaemia, diabetes mellitus, hypertension, smoking, male gender and family history of premature coronary artery disease. Other than the primary risk factors, hyperhomocysteinemia is on special focus now a days. The detrimental effect of severe hyperhomocysteinemia on the cardiovascular system was first described by Mc Cully ${ }^{1}$. Since then several studies have been conducted in the last four decades regarding the association of hyperhomocysteinemia and cardiovascular disease.

Homocysteine (HCY) is a sulfydryl aminoacid that lies at an important metabolic branch point of methionine metabolism, between remethylation and transulfuration pathways ${ }^{2}$.
This lead to the formation of methionine and cystathionine respectively. Several enzymes regulate these pathways under normal condition in the presence of Vit. B12, B 6 and Folic acid. Abnormality in any of the enzymes or vitamin deficiency may give rise to hyperhomocysteinemia. Hyperhomocysteinemia has been classified as: Moderate (Hcy $>15$ to 30 $\mu \mathrm{mol} / \mathrm{L}$ ), Intermediate (Hcy $>30$ to $100 \cdot \mu \mathrm{mol} /$ L) and Severe $(\mathrm{Hcy}>100 \mu \mathrm{mol} / \mathrm{L})^{3}$.

The exact mechanism of atherothrombosis associated with hyperhomocysteinemia is not clearly understood. Several studies have pointed to an association with inhibition of thormbomoduline activity, reduction of protein $c$ activation, increased platelet aggregation, and predisposition to endothelial injury. Moreover, hyperhomocysteinemia induce smooth muscle proliferation, accelerate oxidation of LDL cholesterol, impair endothelial derived nitric

1. Dr. Nur Alam, Dr. Abdul Wadud Chowdhury, Dr. Md. Azizul Hasan Khondoker, Department of Cardiology, $\mathrm{DMCH}$,

2. Dr. Mohammad Zaid Hossain, Dr. Md. Uzzwal Mallik, Department of Medicine, DMCH.

3. Dr. Md. Rasul Amin, Department of Cardiology BSMMU

4. Dr. G M Sadik Hasan, Department of Medicine, BSMMU

Correspondence : Dr. Nur Alam, Department of Cardiology, DMCH, Dhaka 
oxide, decrease synthesis of heparan sulphate proteoglycan and also induce proinflammatory changes in the vessel wall ${ }^{4}$.

There is a recently reported paper regarding an association between homocysteine concentration and plasma markers of thrombosis activation in patients presenting with $\mathrm{ACS}^{5}$. These results postulate that elevated Hcy concentration would lead to increased myocardial injury in those patients group.

The present study is intended to see the level of serum homocysteine in acute myocardial infarction patients. This information would help to focus on the detrimental effect of homocysteine on cardiovascular disease. So measures could be taken to control serum homocysteine along with other risk factors of cardiovascular diseases.

\section{Materials and Methods}

This was a cross sectional study conducted among the patients admitted with acute myocardial infarction in the dept. of cardiology Dhaka Medical College Hospital (DMCH) during the period of October 2009 to September 2010. A total of 194 consecutive patients with acute myocardial infarction (AMI) were included in the study.

The inclusion criteria : Patients with AMI admitted in the dept. of cardiology DMCH; whoose serum homocysteine was measured. The exclusion criteria were patients having cardiomyopathy, congenital heart disease, vulvular heart disease; patients with severe comorbid condition; patients having previous MI, percutaneous coronary intervention, coronary artery bypass grafting; patients already taking folic acid, vit.B-6, vit. B-12 or any of them and patients unwilling to give consent.

Informed consent was taken from each patient. Patient's name and particulars were recorded in the case record file. Initial evaluation of the patients by history and clinical examination was performed and recorded in the preformed data collection sheet. Demographic profile and Pulse, BP, Body weight, were noted. Risk factors of ischaemic heart disease like hypertension, smoking, dyslipidaemia, diabetes mellitus, obesity and family history of premature CAD were noted. Drug history was taken regarding anti hypertensive, lipid lowering and and vitamin (B 6, B 12, Folic acid) supplements.
Baseline laboratory investigations e.g. Serum creatinine, lipid profile, RBS, ECG, Echocardiography, were done for each patient. Serum total homocysteine was measured on fasting sample. Cardiac troponin I (cTI) which reflects the degree of myocardial injury was measured after 10 to 12 hours of onset of symptoms (peak cTI). All the information were properly noted in the preformed data sheet. Serum homocysteine level was measured on fasting sample by Fluorescence Polarization Immuno Assay (FPIA) method and was recorded in units of $\mu \mathrm{mol} / \mathrm{L}$. The test was done in the 'Biochemistry Department' of Bangabandhu Sheikh Mujib Medical University (BSMMU). Data was analyzed by Statistical Package For Social Science (SPSS).The statistical tests used to analyze the data were: Descriptic statistics, multiple logistic regressions test and unpaired t test. Level of significance was set at 0.05. Prior to commencement of this study the respective authority approved the research protocol. All the patients included in this study were informed about the nature, risk and benefit of the study. Proper permission was taken from the department and institution concerned for this study.

\section{Results}

The mean age was $42.8 \pm 12.1$ years with range from 21 to 75 years. Male female ratio was almost 9.8:1 (Fig.-1). Most of the patients were business man $(41.2 \%)$ and service holder $(18.6 \%)$. More than half $(56.7 \%)$ of the patients had chest pain, $39.2 \%$ had breathlessness, $11.3 \%$ had chest discomfort and $3.1 \%$ had other clinical presentations. Most of the patients had Anterior Myocardial Infarction (Antero septal, Anterior \& Extensive Anterior) (90.8\%). Only $19.3 \%$ patients had Inferior Myocardial Infarction (some had double wall infarct). Smoking $(72.2 \%)$, hypertension $(48.5 \%)$, dyslipidaemia (35.1\%) and diabetes mellitus $(34.0 \%)$ were the common risk factors in this study patients (Fig. -2$)$. The mean ( \pm SD) serum homocysteine level was $20.2 \pm 14.3 \mathrm{mmol} / \mathrm{L}$ with range from 7.4 to $129.1 \mathrm{mmol} / \mathrm{L}$ (Table I). Serum homocysteine level was significantly $(\mathrm{p}<0.05)$ higher among smoker and dyslipidemia (Table II), but association with other risk factors were not significant $(p>0.05)$. Multiple logistic regression model test (Table III) showed that along with smoking and diabetes, serum homocysteine level is an 
important risk factor determining the extent of myocardial injury.

Figure 1 shows the sex distribution of the patients and it was found that $176(90.7 \%)$ male and $18(9.3 \%)$ female and male female ratio was almost 9.8:1 in this study patient.

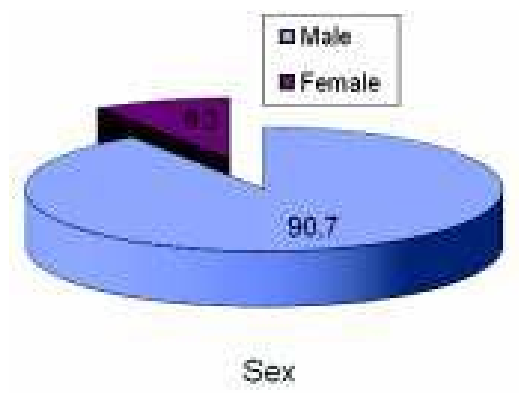

Table I

Distribution of the study patients according to serum homocysteine level $(\mathrm{mmol} / \mathrm{L})(\mathrm{n}=194)$

\begin{tabular}{lcc}
\hline $\begin{array}{l}\text { Serum homocysteine } \\
\text { level }(\mathrm{mmol} / \mathrm{L})\end{array}$ & $\begin{array}{c}\text { Number } \\
\text { of patients }\end{array}$ & Percentage \\
\hline Normal $(<15 \mathrm{mmol} / \mathrm{L})$ & 74 & 38.1 \\
High $(>15 \mathrm{mmol} / \mathrm{L})$ & 120 & 61.9 \\
Mean \pm SD & 20.2 & \pm 14.3 \\
Range $(\min -\max )$ & $(7.4$ & $-129.1)$ \\
\hline
\end{tabular}

Figure 2 shows distribution of the study patients according to traditional risk factors $(n=194)$

Fig.-1: Pie diagram showing the sex distribution of the study patients.

\section{Table-II}

Mean distribution of Serum homocysteine level $(\mathrm{mmol} / \mathrm{L})$ according to traditional risk factors in the study patients $(n=194)$

\begin{tabular}{|c|c|c|c|c|c|}
\hline \multirow{2}{*}{ Risk factors } & \multicolumn{2}{|c|}{ Serum homocysteine level } & \multirow{2}{*}{$\begin{array}{c}\mathrm{t} \\
\text { Value }\end{array}$} & \multirow[b]{2}{*}{$\mathrm{df}$} & \multirow{2}{*}{$\begin{array}{c}\mathrm{P} \\
\text { Value }\end{array}$} \\
\hline & $\begin{array}{l}\text { Risk factor } \\
\text { present } \\
\text { Mean } \pm \text { SD }\end{array}$ & $\begin{array}{c}\text { Risk factor } \\
\text { Absent } \\
\text { Mean } \pm \text { SD }\end{array}$ & & & \\
\hline Smoking & $21.7 \pm 16.2$ & $16.3 \pm 5.7$ & 2.40 & 192 & $0.017^{\mathrm{s}}$ \\
\hline Hypertension & $18.6 \pm 8.8$ & $21.7 \pm 17.9$ & -1.53 & 192 & $0.128^{\mathrm{ns}}$ \\
\hline Diabetes mellitus & $17.5 \pm 8.0$ & $21.6 \pm 16.5$ & -1.91 & 192 & $0.058^{\text {ns }}$ \\
\hline Family H/O premature CAD & $18.7 \pm 9.6$ & $20.7 \pm 15.5$ & -.86 & 192 & $0.391^{\mathrm{ns}}$ \\
\hline Dyslipidaemia & $23.8 \pm 20.4$ & $18.3 \pm 9.0$ & 2.60 & 192 & $0.010^{\mathrm{s}}$ \\
\hline Obesity & $19.1 \pm 9.6$ & $20.5 \pm 15.1$ & -.54 & 192 & $0.591^{\mathrm{ns}}$ \\
\hline
\end{tabular}

ns=not significant, $\mathrm{s}=$ significant

$\mathrm{p}$ value reached from unpaired t-test

Table III

Association of serum homocysteine and and other risk factors with increase serum troponin-I by multiple logistic regression models ( $n=194)$

\begin{tabular}{lccccccc}
\hline & B & S.E & df & Sig & OR & \multicolumn{2}{c}{$95 \%$ CI for OR } \\
& & & & & & Lower & Upper \\
\hline Smoking & 2.35 & 0.858 & 1 & $0.006^{\mathrm{s}}$ & 1.96 & 0.39 & 5.71 \\
Hypertension & 1.093 & 0.672 & 1 & $0.104^{\mathrm{ns}}$ & 2.90 & 0.80 & 11.13 \\
Diabetes mellitus & 1.569 & 0.712 & 1 & $0.027^{\mathrm{s}}$ & 4.80 & 1.19 & 19.3 \\
Family H/O premature CAD & 0.715 & 0.776 & 1 & $0.357^{\mathrm{ns}}$ & 2.05 & 0.45 & 9.36 \\
Dyslipidaemia & 0.356 & 0.714 & 1 & $0.618^{\mathrm{ns}}$ & 0.70 & 0.17 & 2.84 \\
Obesity & 0.297 & 0.827 & 1 & $0.719^{\mathrm{ns}}$ & 1.35 & 0.27 & 6.81 \\
Serum homocysteine level $(>15 \mathrm{mmol} / \mathrm{L})$ & 1.958 & 0.726 & 1 & $0.001^{\mathrm{s}}$ & 7.09 & 1.71 & 29.41 \\
Constant & 4.920 & 1.365 & 1 & 0.001 & 0.01 & & \\
\hline
\end{tabular}




\section{Discussion}

In this study it was found that the mean age was $42.8 \pm 12.1$ years with range from 21 to 75 years. Maximum number of patients were found in the age group of 31-40 years. Obaidi et al. ${ }^{5}$ observed higher mean age of the patients $(67.3 \pm 1.9$ years and $58.6 \pm 10.9$ years.

In the current study male female ratio was almost 9.8:1 in this study patients. Almost similar results were obtained by Obaidi et al. in his study. Puri et al. ${ }^{13}$ mentioned that CAD affects males more severely and commonly than females; this has been attributed to the protective effect of estrogen in premenopausal females. They also suggested that, the lower female percentage might be due to social customs that restrict women seeking medical help outside the home even in the face of serious illness.

In the current study it was found that most of the patients had Anterior Myocardial Infarction (Antero septal, Anterior \& Extensive Anterior) (90.8\%). Only $19.3 \%$ patients had Inferior Myocardial Infarction (some had double wall infarct). In another study Dey ${ }^{8}$ found $54.3 \%$ had Anterior MI and 45.7\% had Inferior MI.

In the present study, serum homocysteine values were categorized into normal $(<15 \mu \mathrm{mol} /$ L) and high (e" $15 \mu \mathrm{mol} / \mathrm{L})$ values. It was found that most (120) $(61.9 \%)$ of the patients had high serum homocysteine level and 74 (38.1\%) had normal level. The mean $( \pm \mathrm{SD})$ serum homocysteine level was $20.2 \pm 14.3 \mathrm{mmol} / \mathrm{L}$ with range from 7.4 to $129.1 \mathrm{mmol} / \mathrm{L}$.

El Oudi et al. ${ }^{6}$ observed that the mean serum homocysteine level was $17.67 \pm 8.32 \mu \mathrm{mol} / \mathrm{L}$ in ACS patients. Sadeghian et al. ${ }^{7}$ observed that the mean level of serum homocysteine in young CAD patients was $19.3 \pm 1.7 \mu \mathrm{mol} / \mathrm{L}$ which is consistent with the current study. Obaidi et al. ${ }^{5}$ observed mean \pm SD serum homocysteine level $11.3 \pm 1.3 \mathrm{mmol} /$ liter in $\mathrm{MI}$ and $11.2 \pm 1.4$ $\mathrm{mmol} /$ liter in UA patients, which is a bit less than the current study finding.

Regarding the risk factors of cardiovascular disease it was observed that the mean $( \pm \mathrm{SD})$ serum homocysteine level ( $\mathrm{mmol} / \mathrm{L})$ were significantly $(\mathrm{p}<0.05)$ higher in smoker $(21.7$ vs $16.3 ; \mathrm{p}=0.017)$ and in dyslipidemia (23.8 vs 18.3; $p=0.010$ ) but other risk factors were not significantly $(p>0.05)$ associated. These findings are consistent with the reports from Dey ${ }^{8}$ where the author found that serum homocysteine level was significantly higher among the subjects with smoking, dyslipidaemia and family history of ischaemic heart disease $(p<0.05)$, but no statistically significant association of serum homocysteine level was found with diabetes Mellitus (DM) and hypertension (HTN) ( $>0.05)$. However the European Concerted Action Project ${ }^{9,10}$ has observed stronger association between serum total homocysteine level and hypertension. In our study by multiple logistic regression test it was found that along with smoking and diabetes, plasma homocysteine level is an important risk factor determining the extent of myocardial injury measured by cardiac troponin I level, a surrogate marker. Page et al. ${ }^{11} \&$ Souissi et al. ${ }^{12}$ found independent association between high serum homocysteine and increased risk of myocardial infarction.

Elevated levels of serum homocysteine may result from geographical variations, racial and ethnic differences, genetic causes, different lifestyle, inadequate intake of B vitamins and folate, inaccurate cooking of vegetables and not implementing fortification of grain products with folic acid. The results of the study may have important implications for prevention of mortality and morbidity from acute myocardial infarction in Bangladeshi population.

The results of the current study suggests further studies are required to assess the effect of homocysteine lowering treatment for primary prevention of coronary artery disease.

\section{Conclusion}

The main observation of the present study was that significant number of patients of acute myocardial infarction had elevated serum homocysteine level. Other than the primary risk factors associated with the development of atherosclerotic coronary artery disease like hypertension, diabetes mellitus, hyperlipidaemia, smoking, male gender and family history of premature coronary artery disease, hyperhomocysteinemia should be on special focus. 


\section{Study limitation}

There are some facts which might affect the result

- Number of study population was limited.

- It was a single center study

\section{Acknowledgement}

The authors wish to acknowledge the staff of dept. of Cardiology, Dhaka Medical College Hospital and the patients and their attendants for their kind consent and cooperation.

\section{References}

1. McCully KS. Vascular pathology of homocysteinemia: implication of the pathogenesis of arteriosclerosis. American Journal of Pathology 1969; 56: 111-28.

2. Selhub JHomocysteine metabolism. Annu Rev Nutr 1999;19:217-46.

3. Maron DJ, Rider PM, Grundy SM. Prevention Strategies for Coronary Heart Disease. In: Fuster V, Walsh RA, O'rourke RA, Wilson PP, editors, Hurst's, the heart, $12^{\text {th }}$ edn, Mc Graw Hill, New York, USA,2008 : 1235.

4 Hayashi T, Honda G, Suzuki K An atherogenic stimulus homocysteine inhibits cofactor activity of thrombomodulin and enhances thrombomodulin expression in human umbilical vein endothelial cells. Blood 1992; 79: 29302936.

5. Obaidi MK, Stubbs PJ, Collinson P, Conroy R, Graham I, Noble MIM Elevated Homocysteine Levels Are Associated With Increased Ischemic Myocardial Injury in Acute Coronary Syndromes. JACC 2000; 36(4): Hyperhomocysteinemia and Ischemic Myocardial Injury, October, 1217-22.
6. Oudi M EL, Aouni $Z$, mazigh C, Khochkar R, Gazoueni E, Haouela $\mathrm{H}$ et al. Homocysteine and markers of inflammation in acute coronary syndrome. Exp Clin Cardiol 2010;15(2): e25-e28.

7. Sadeghian S, Fallahi F, Salarifar M, Davoodi G, Mahmoodian M, Fallah $\mathrm{N}$ et al. Homocysteine, vitamin B12 and folate levels in premature coronary artery disease. BMC Cardiovascular Disorders 2006; 6:38.

8 Dey A. Plasma homocysteine level as a risk factor for acute myocardial infarction (thesis). Dhaka: BSMMU 2002; 96p

9. Graham IM, Daly LE, Refsum HM, Robinson K, Brattstrom LE, Ueland PM et al. Plasma homocysteine as a risk factor for vascular disease: the European Concerted Action Project. JAMA 1997; 277:1775-81.

10. Verhoef P, Stampfer MJ, Buring JE, Goziano JM, Allen RH, Stabler SP et al. Homocysteine metabolism and risk of myocardial infarction: Relation with vitamin $\mathrm{B}_{6}, \mathrm{~B}_{12}$ and folate. Am J Epidemiology1996 ;143: 845-858.

11. Page JH, Ma J, Chiuve SE, Stampfer MJ, Selhub $\mathrm{J}$, Manson JE et al. Plasma total cysteine and total homocysteine and risk of myocardial infarction in women: a prospective study. Am Heart J 2010; 159(4): 599-604.

12. Souissi M, Feki M, Mourali S, Enneifer M, Omar $\mathrm{S}$, Sanhaji $\mathrm{H}$ et al. Homocysteinemia and coronary artery disease: a case-control study in a Tunisian population. Arch Mal Coeur Vaiss 2006 ; 99(9): 781-5.

13 Puri A, Gupta OK, Dwivedi RN, Bharadwaj RPS, Narain VS, Singh S 2003, 'Homocysteine and Lipid levels in young patients with coronary artery disease', JAPI, vol. 51, pp. 681-685. 